\title{
Does it Pay to Watch Central Bankers' Lips? The Information Content of ECB Wording
}

\author{
Friedrich Heinemann* and Katrin Ullrich**
}

JEL-Classification: E 52, E 43

Keywords: Taylor rule, wording, central bank communication

\section{Introduction}

Central bank watchers, financial media and market participants pay considerable attention to central bankers' statements. Even slight nuances of wording are being scrutinised with regard to possible signals about future monetary policy decisions. In the financial press, lists of code words are reported together with their alleged monetary policy interpretation (e.g., WithOUT AUTHOR, 2003). Examples exist where the linguistic analysis of central bank publications is used to construct a measure of rhetoric "hawkishness", which then serves as an input for assessing the monetary policy outlook (MAYER, 2004).

Practitioners' interest into central bank communication is increasingly mirrored in the academic literature as well. Central bank communication is acknowledged as an important element in the conduct of monetary policy. Through their words central bankers try to influence expectations and also the perceived credibility of the central bank.

* Centre for European Economic Research (ZEW), Mannheim, PO Box 103443, D-68034 Mannheim, Tel. +49 (0)621 1235-149, Fax +49 (0)621 1235-223, heinemann@zew.de. We are grateful for helpful comments from Carlo Rosa, Michael Ehrmann, Lucian Orlowski and the participants of the National Bank of Poland Conference "Central Bank Transparency and Communication: Implications for Monetary Policy" in Warsaw in June 2005, from Etienne Farvaque and the participants of the $22^{\text {nd }}$ Symposium on Banking and Monetary Economics in Strasbourg in June 2005 as well as from two anonymous referees. We thank Gunnar Lang for able research assistance.

** Centre for European Economic Research (ZEW), Mannheim and 'WIN-Kolleg' of the Heidelberg Academy of Sciences, PO Box 103443, D-68034 Mannheim, Tel. +49 (0)621 1235145, Fax +49 (0)621 1235-223, ullrich@zew.de. 
The literature on central bank communication in general and ECB communication in particular has developed along different avenues. A number of contributions have been successful to establish a clear impact of communication on financial market variables like exchange rates or interest rates other than the policy rate. ANDERsson et al. (2001) establish that the long-term interest rates are influenced by signals from speeches of central bankers from the Swedish central bank. Guthrie and Wright (2000) find an announcement effect for interest rates along all maturities in the case of New Zealand. Also, the Bank of England influences interest rates by different channels of communication, most pronounced for the minutes of the meetings and the Inflation Report (ReEves and SAWicki, 2005). KoHN and SACK (2003) find that the Federal Reserve also influences short- and long-term interest rates with different communication devices. The effect of ECB policy announcement on Euribor futures market rates seems to be small (Bernoth and von Hagen, 2004). Studies related to the impact of communication on exchange rates are Fratzscher (2004), JANSEN and DE HAAN (2004b), or Beine and Lecourt (2004). Lamla and Rupprecht (2006) establish a link between ECB statements and the term structure of the interest rate.

Furthermore, communication has been analyzed with a focus on central bank transparency, predictability, the consistency of statements or its impact on the media. For example, Ross (2002) examines the predictability of ECB policy decisions concluding that the predictability of the ECB is lower than that of the Fed or the Bank of England. Gaspar et al. (2001), Wilhelmsen and Zaghini (2005) and Ehrmann and Fratzscher (2005) come to more favourable conclusions. For the Fed, Conley et al. (2004) show that the bias announcement includes significant information, which may help to predict the Federal Reserve's interest rate decisions. FaUST, SWANSON and WRIGHT (2004) find little evidence that monetary policy surprises from the Federal Reserve convey superior information that may be used to improve the private sector forecast of statistical releases. JANSEN and De HAAN (2004a) detect a certain inconsistency between statements of central bankers from the ECB and the national central banks of the euro area. JANSEN and DE HAAN (2005), for the first years of the ECB, show that a Taylor type ordered probit estimation outperforms communication based predictions of interest rate changes. BERGER et al. (2006a) finally ask how communication impacts on media coverage and the acceptance of the ECB decisions in the media.

We want to contribute to this growing literature in two respects. First, we shift the focus back to the issue dominating practitioners' attention. Basically, in the financial markets central bank observers want to infer from central bankers' statements what the future interest rates will be. Here we ask to which extent 
the wording of the ECB president in the monthly press conference is actually informative in this respect. In essence, we deal with two distinct, but closely related questions: Is central bank watching based solely on a counting of code words an efficient information technique in the sense that this strategy does not perform substantially worse than other more subtle techniques? And does a wording indicator in addition to model based processing of economic data offer valuable information for the explanation of central bank rates? Our point of reference for a standard model explaining monetary policy decision making is a Taylor rule specification.

Our second contribution is to offer a more objectively constructed wording indicator. Here, we address a major challenge the empirical literature on central bank communication is confronted with: the need to transform words and arguments being used by central bankers into quantitative indicators. In the literature cited above, different ways have been taken to tackle that problem. Authors like Rosa and Verga (2005) or Gerlach (2004) make use of wording indicators whose common characteristic is, however, a subjective construction. This means that the authors' own judgement guides the interpretation of certain formulations of ECB representatives and the sign and weights of code words in the overall indicator. BERGER et al. (2006b) limit this problem by classifying statements through parallel teams of researchers working independently from each other. We offer an alternative solution based on an objective decoding algorithm exploiting the observable significant differences in the use of certain words and expressions prior to interest rate increases, decreases or in passive phases.

Our results support the rationality of central bank watchers' attention for linguistic specificities. Although the reading of central bankers' lips cannot substitute the careful analysis of hard economic data it, nevertheless, offers additional insights. Obviously, ECB wording has an information content which cannot fully be replicated by Taylor type regressions based on macroeconomic data only. Thus, it is rational information collecting when market actors pay attention to the subtleties of wording.

In the next section we give a brief exposition of our analytical strategy, followed by the construction of a wording indicator in section 3. Section 4 presents our model structure and Section 5 the estimation results. Section 6 summarizes our findings and concludes. 


\section{Analytical Approach}

There are basically two different potential explanations for the markets' attention to central bank wording. Our empirical strategy is designed to differentiate between both. First, information strategies based on the exegesis of central bank statements may be a cost-efficient alternative to more rigorous approaches based on implicit or explicit models and a collection of all relevant data. The Fed's former bias announcement illustrates this interpretation: If a central bank credibly states what it intends to do in the coming months, market participants could try to economize on forecasting efforts and - in the extreme - even stop devoting any resource to this activity apart from following official statements. The second explanation points towards a less demanding function of rhetoric signals. Even if these signals may not be able to replace more thorough forecasting techniques, they might be useful to improve these forecasts.

The recent literature on central bank communication offers a number of reasons why wording could have this informative content which should at least be not fully substitutable by a model based solely on economic data. Communication is a key element in monetary policy's task of managing expectations (BERGER et al., 2006b). One objective is to limit uncertainty about the course of monetary policy. Hence, the rhetoric signals sent out by the central bankers should offer insights about the central bank's perceptions and intentions. LAmLA and RupPRECHT (2006) underline this idea with regard to price developments: the way a central bank regards current inflation trends as transitory or permanent is essential to transform current inflation data into interest rate expectations. This should be particularly relevant in times when a central bank is perceived as missing its targets. Indeed, BERGER et al. (2006a) show that the coverage of ECB policy in the print media is more negative when inflation is relatively high laying base of the ECB's self-interest in explaining its perceptions and plans. Hence, it should be expected that wording has an information content going beyond knowledge available to the public. Furthermore, the relative short history of the ECB is an argument in favour of model uncertainty on the side of ECB watchers. For example, it may be unclear how (common knowledge) data on heterogeneous developments in the Euro zone affect the decision making in the Council (Heinemann and HüFNER, 2004). In these cases, wording signals can be an input to forecasting models being able to improve the model's fit.

Our empirical strategy tests for both potential functions of ECB watching, i.e. first a full substitution of model based forecasting of ECB decisions, and, second, the combination of a model based approach with the inclusion of information from wording. Consequentially, we test the following two distinct hypotheses: 
Hypothesis 1: Central bank watching and de-coding of wording is a substitute for thorough model analyses.

Hypothesis 2: Wording includes information helpful to improve the explanation of interest rate decisions based on standard explanatory models.

In order to test hypothesis 1 , we check the fit of a model explaining ECB rates solely on the basis of their own history and our wording indicator. Hypothesis 2 is tested by augmenting a standard Taylor equation with our wording indicator as additional regressor. Before proceeding with this strategy, in the following section, we describe the construction of our wording indicator.

\section{The Construction of the Wording Indicator}

Our wording indicator is constructed by an algorithm which allows for an objective (statistically based) weighting of code words and thus needs no subjective assessment with regard to the alleged importance of certain signal words. The algorithm's main idea is that only those code words are taken into account whose frequency of use is significantly different in distinct monetary policy phases. How much of this is explained by the significant differences in use determines the weight of the word in the indicator construction. Furthermore, a positive (negative) sign is attached to these code words depending on whether they are more often used prior to increases (decreases) of interest rates.

The algorithm is based on a full interest rate cycle starting in 1999:01 and ending in 2001:12 allowing for the use of code words both in expansionary and contractive phases. Thus, the algorithm assumes that a full interest rate cycle has been necessary for ECB observers to decode the relevance of potential signal words and expressions.

For the subsequent testing it is essential that the algorithm does not exploit the available dataset fully in order to avoid a within-sample fallacy: If the derivation of the wording indicator were based on the full data sample it would by construction safeguard a good fit in any model explaining interest rate decision. Limiting its construction on the information from a sub-sample allows for testing the indicator's information content out of sample. More precisely the algorithm has the following steps:

\section{Step One: Identifying Code Words with Information Content}

The use of code words in the introductory statement of the monthly ECB press conference is counted. In those few months (8 out of 99 observations) where no press conference took place we take the editorials of the monthly ECB reports 
as substitute which are very similar in contents, length and terminology to the press conferences' initial statements. Note, however, that we drop the press conference observations from the regressions presented in section 5 in order to safeguard a clear focus on the information content of the press conferences. In order to achieve a high degree of objectivity we abstain from taking into account the context of the terms' use apart from unequivocal negations. For example, we do treat a statement like "there is no risk to price stability" as if "risks to price stability" was not mentioned. We then group observations into monetary policy phases of neutrality, tightening or easing. Our grouping criterion is simply the observed interest policy of the two months following the press conference. We feed into the testing a large number of potential code words which are on the lists circulating among practitioners (WITHOUT AUTHOR, 2003) and which are used in the related academic studies (e.g. Rosa and Verga, 2005). Table A in the appendix lists the code words included into the analysis.

We also include a variable measuring the length of the President's introductory statement devoted to monetary policy into our initial list. This length is not affected by technical discussion such as the euro changeover or the expansion of the euro zone since these technical discussions constitute clearly separate parts of the statement and are not included in our word count. There a contradicting arguments to the expected information content of length so that its information content is ambiguous a priori: On the one hand, the length of the statement should be a signal if the preparation of a change in interest rates needs more words compared to a situation of continuing passivity. On the other hand, the president may feel obliged to vindicate the central bank council's position in greater detail if the public is critical of a too passive ECB.

Figure 1 shows frequency means of code words depending on the character of the monetary policy stance judged on the basis of the interest rate decision in the following two months. Press conferences preceding interest rate increases are characterized by a more frequent use of "vigilant", "risks to price stability/inflation", "second round effects" or "favourable outlook for growth". During more passive stages, the ECB president more frequently uses words like "in line" and "balanced". Code words used more frequently in phases preceding interest rate cuts are "appropriate", "to monitor", "downside risks to growth" or "economic slowdown".

We proceed by eliminating those words whose frequencies of use do not significantly differ among monetary policy phases. Among others, the difference in the mean length of the statements misses significance and, hence, drops out of the wording indicator construction as well. Table 1 summarises the results of ANOVA tests for the equality of means in the frequency of these words' frequencies for the period January 1999 - December 2001 which comprises a complete 
interest rate cycle and thus should be sufficient to derive the signalling content of ECB statements. For the elimination procedure we work with a critical level of significance of 5 percent (and 10 percent for a robustness check).

\section{Step Two: Deciding the Sign and Weight of Significant Code Words}

Since the ANOVA tests assess differences in mean across all groups, it does not give a direct insight on pair-wise differences. For this purpose, we present least significant distance tests (Table 2) for the words with significant F-tests indicating which of the pair-wise differences in means show significance.

The significant pair-wise tests are used to decide the sign of the specific code word in our indicator. A positive sign is attributed to those words for which tests significantly show larger frequencies in tightening compared to easing periods, tightening compared to neutral periods or in neutral compared to easing periods. A negative sign is assigned to words where the significant relative frequencies are opposite. Thus, the resulting indicator is, by construction, positively associated with an increasing "hawkishness" of ECB rhetoric.

Additional information for the learning oriented construction of our wording indicator comes from the $\eta^{2}$ statistic (included in Table 1) measuring the share of the total variance attributable to differences in means between the three different kinds of periods. The $\eta^{2}$ statistic is used to provide a weight for the informational contents of different code words.

\section{Step Three: Calculation of the Wording Indicator WI}

Finally, our wording indicator WI is constructed using frequency of code words $\mathrm{x}_{\mathrm{i}}$ as follows:

$$
W I_{t}=\sum_{i=1}^{k} \frac{\operatorname{nobs}\left(x_{i, t}\right)-\text { meanobs }\left(x_{i}\right)}{\operatorname{std} v\left(x_{i}\right)} \operatorname{sign}\left(x_{i}\right) \eta^{2}\left(x_{i}\right)
$$

The indicator adds for each period the (standardized) number of observations. These numbers are weighted by the $\eta^{2}$ statistic in order to account for the differences in the informational content of code words. The sign of each individual code word is determined on the basis of significant pair-wise tests as described in Tables 3 and 6.

The calculations result in two indicators based on the 5 and the 10 percent significance level as cut-off points for the inclusion of potential code words in the first step. Figure 2 presents the two indicators together with the fixed rate (until June 2000) respective the minimum bid rate of the main refinancing operations (MRO). The high correlation of both indicators shows that the outcome of our algorithm is not very sensitive to the choice of the critical significance level. 
Figure 1: Frequency Means of Code Words in Press Conferences Depending on Monetary Policy Phase (1999:01-2001:12)

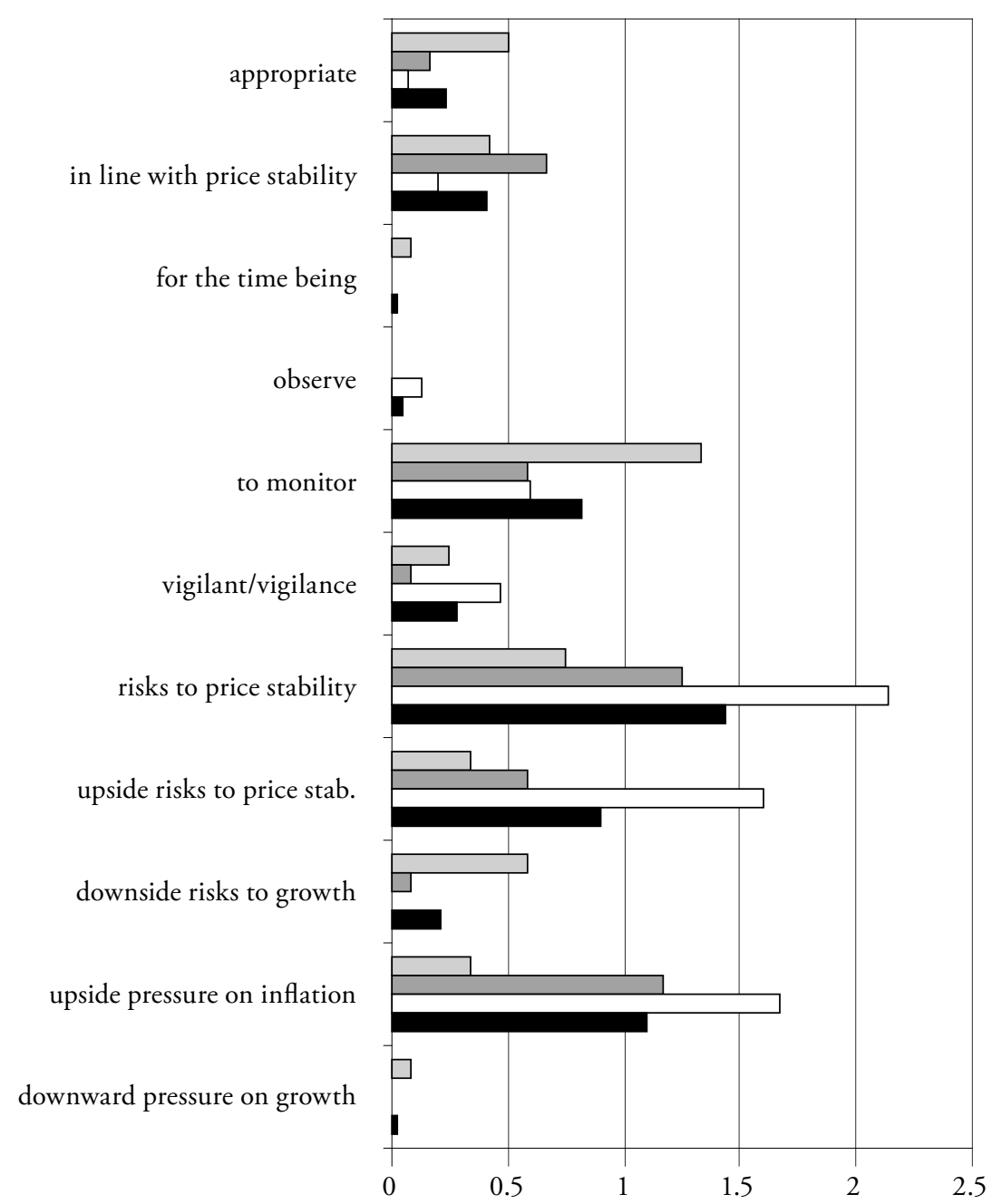




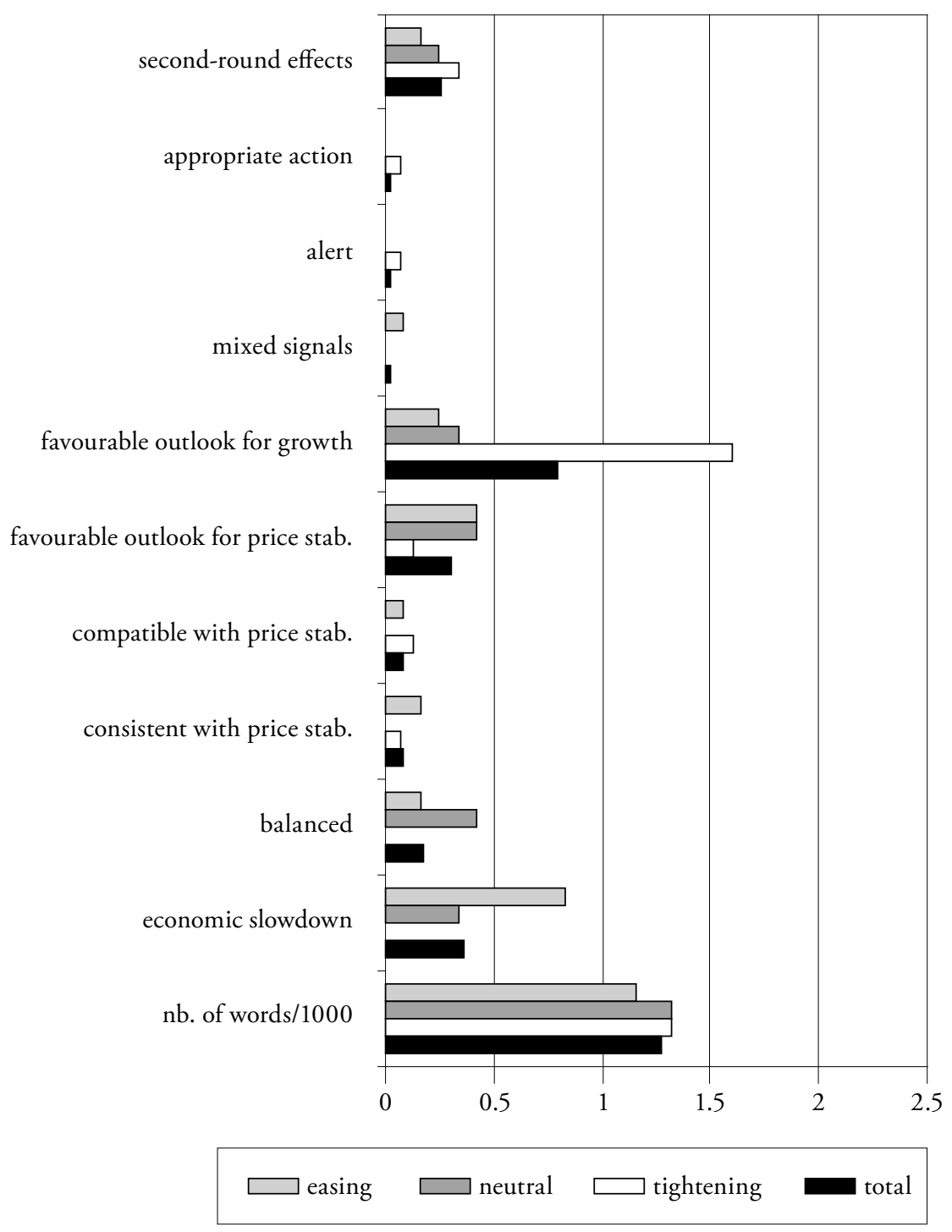


Table 1: Analysis of Variance - Full Interest Rate Cycle 1999:01-2001:12

\begin{tabular}{|c|c|c|c|}
\hline & F-statistic & significance & $\eta^{2}$ \\
\hline appropriate & 3.13 & 0.056 & 0.148 \\
\hline in line with price stability & 2.18 & 0.128 & 0.108 \\
\hline for the time being & 1.13 & 0.333 & 0.059 \\
\hline observe & 1.70 & 0.196 & 0.086 \\
\hline to monitor & 3.26 & 0.050 & 0.153 \\
\hline vigilant/vigilance & 2.60 & 0.088 & 0.126 \\
\hline risks to price stability & 4.79 & 0.014 & 0.210 \\
\hline upside risks to price stability & 6.01 & 0.006 & 0.250 \\
\hline downside risks to growth & 3.84 & 0.031 & 0.176 \\
\hline upside pressure on inflation & 4.50 & 0.018 & 0.200 \\
\hline downward pressure on growth & 1.13 & 0.333 & 0.059 \\
\hline second round effects & 0.46 & 0.634 & 0.025 \\
\hline appropriate action & 0.79 & 0.461 & 0.042 \\
\hline alert & 0.79 & 0.461 & 0.042 \\
\hline mixed signals & 1.13 & 0.333 & 0.059 \\
\hline favourable outlook for growth & 11.63 & 0.000 & 0.393 \\
\hline favourable outlook for price stability & 1.39 & 0.261 & 0.072 \\
\hline compatibe with price stability & 0.81 & 0.453 & 0.043 \\
\hline consistent with price stability & 1.17 & 0.321 & 0.061 \\
\hline balanced & 1.97 & 0.154 & 0.099 \\
\hline economic slowdown & 5.11 & 0.011 & 0.221 \\
\hline Number of words & 1.59 & 0.218 & 0.081 \\
\hline
\end{tabular}

Note: 39 observations (two press conferences in March 2000, October 2000 and June 2001). The $\eta^{2}$ statistics is computed as between-groups sum of squares divided by total sum of squares. 
Table 2: Pair-wise Differences in Means (Least Significance Distance) 1999:01-2001:12

\begin{tabular}{|c|c|c|c|}
\hline $\begin{array}{l}\text { Code word (mean frequency per } \\
\text { press conference) }\end{array}$ & & $\begin{array}{c}\text { difference in } \\
\text { mean }\end{array}$ & significance \\
\hline $\begin{array}{l}\text { appropriate } \\
(0.23)\end{array}$ & $\begin{array}{l}\text { neutral vs. easing* } \\
\text { tightening vs. easing** } \\
\text { tightening vs. neutral }\end{array}$ & $\begin{array}{l}-0.33 \\
-0.43 \\
-0.10\end{array}$ & $\begin{array}{l}0.084 \\
0.020 \\
0.578\end{array}$ \\
\hline $\begin{array}{l}\text { to monitor } \\
(0.82)\end{array}$ & $\begin{array}{l}\text { neutral vs. easing** } \\
\text { tightening vs. easing** } \\
\text { tightening vs. neutral }\end{array}$ & $\begin{array}{r}-0.75 \\
-0.73 \\
0.02\end{array}$ & $\begin{array}{l}0.035 \\
0.030 \\
0.959\end{array}$ \\
\hline $\begin{array}{l}\text { Vigilant } \\
(0.28)\end{array}$ & $\begin{array}{l}\text { neutral vs. easing } \\
\text { tightening vs. easing } \\
\text { tightening vs. neutral }\end{array}$ & $\begin{array}{r}-0.17 \\
0.22 \\
0.38\end{array}$ & $\begin{array}{l}0.357 \\
0.209 \\
0.030\end{array}$ \\
\hline $\begin{array}{l}\text { risks to price stability } \\
(1.44)\end{array}$ & $\begin{array}{l}\text { neutral vs. easing } \\
\text { tightening vs. easing*** } \\
\text { tightening vs. neutral* }\end{array}$ & $\begin{array}{l}0.50 \\
1.38 \\
0.88\end{array}$ & $\begin{array}{l}0.307 \\
0.005 \\
0.061\end{array}$ \\
\hline $\begin{array}{l}\text { upside risks to price stability } \\
(0.90)\end{array}$ & $\begin{array}{l}\text { neutral vs. easing } \\
\text { tightening vs. easing*** } \\
\text { tightening vs. neutral }\end{array}$ & $\begin{array}{l}0.25 \\
1.27 \\
0.58\end{array}$ & $\begin{array}{l}0.551 \\
0.003 \\
0.013\end{array}$ \\
\hline $\begin{array}{l}\text { downside risks to growth } \\
(0.21)\end{array}$ & $\begin{array}{l}\text { neutral vs. easing** } \\
\text { tightening vs. easing** } \\
\text { tightening vs. neutral }\end{array}$ & $\begin{array}{l}-0.50 \\
-0.58 \\
-0.08\end{array}$ & $\begin{array}{l}0.040 \\
0.013 \\
0.710\end{array}$ \\
\hline $\begin{array}{l}\text { upside pressure on inflation } \\
(1.10)\end{array}$ & $\begin{array}{l}\text { neutral vs. easing* } \\
\text { tightening vs. easing*** } \\
\text { tightening vs. neutral }\end{array}$ & $\begin{array}{l}0.83 \\
1.33 \\
0.50\end{array}$ & $\begin{array}{l}0.085 \\
0.005 \\
0.269\end{array}$ \\
\hline $\begin{array}{l}\text { favourable outlook for growth } \\
(0.79)\end{array}$ & $\begin{array}{l}\text { neutral vs. easing } \\
\text { tightening vs. easing } \\
\text { tightening vs. neutral }\end{array}$ & $\begin{array}{l}0.08 \\
1.35 \\
1.27\end{array}$ & $\begin{array}{l}0.806 \\
0.000 \\
0.000\end{array}$ \\
\hline $\begin{array}{l}\text { Economic slowdown } \\
(0.36)\end{array}$ & $\begin{array}{l}\text { neutral vs. easing* } \\
\text { tightening vs. easing*** } \\
\text { tightening vs. neutral }\end{array}$ & $\begin{array}{l}-0.50 \\
-0.83 \\
-0.33\end{array}$ & $\begin{array}{l}0.077 \\
0.003 \\
0.210\end{array}$ \\
\hline
\end{tabular}

Note: Pair-wise test based on 39 observations between 1999:01 und 2001:12. Included are those code words, for which F-test (Table 1) indicates at least 10 percent significance; ${ }^{*} / * * * * *$ : significance of pair-wise tests at 10/5/1 percent. 
Figure 2: Wording Indicators and the Fixed Rate/Minimum Bid Rate on the MROs.

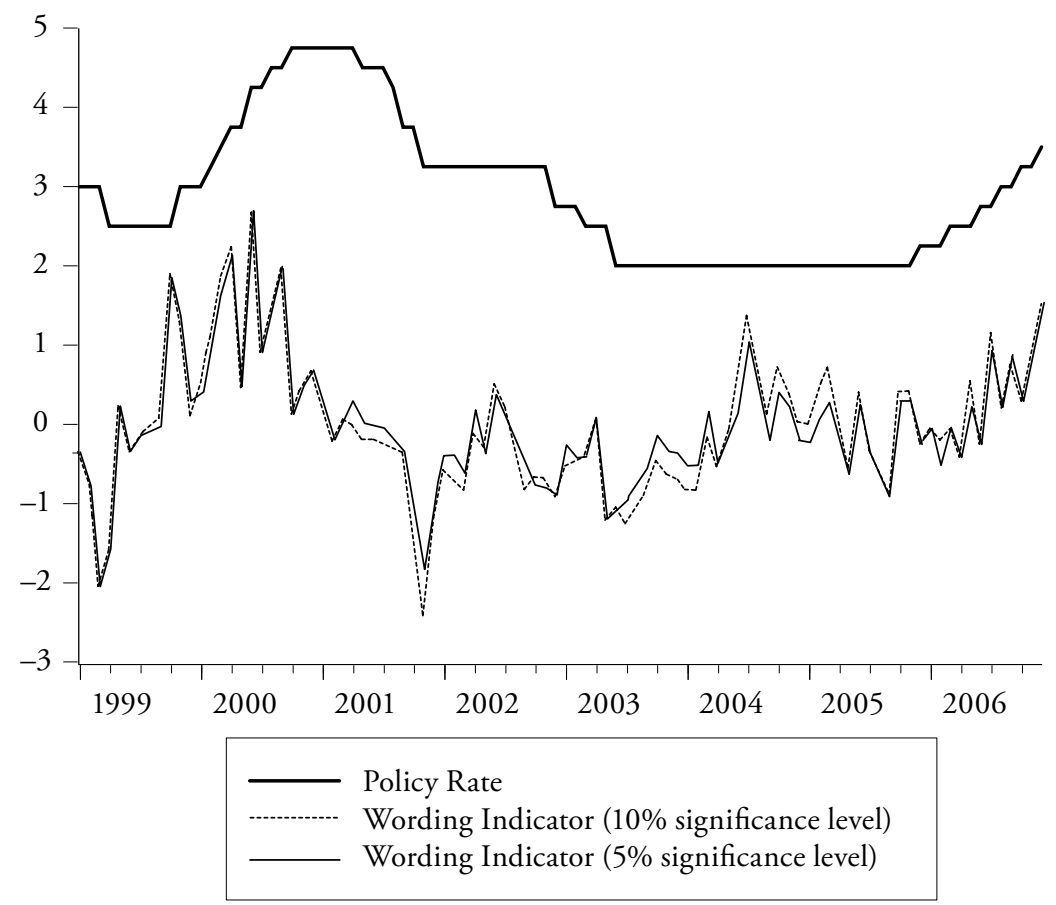

\section{Model, Econometric Approach and Data Issues}

The assessment of the informative content of our wording indicator with regard to hypotheses 1 and 2 is based on a standard model of monetary decision making that is extended to include communication issues. We assume that the ECB defines its target rate, $i_{t}^{*}$, on the basis of a smoothing adjustment towards an interest rate, $i_{t}^{F}$, which is the optimal rate of the fully specified model guiding the decisions of the Council:

$$
i_{t}^{*}=\rho i_{t-1}+(1-\rho) i_{t}^{F}
$$

A Taylor interest rate (TAYLOR, 1993) is most probably an incomplete approximation of $i_{t}^{F}$. We model this by regarding the fully specified model as a weighted average of a Taylor type target rate, $i_{t}^{T}$, and a second target rate, $i_{t}^{O}$, which 
includes those other aspects in Council preferences which are not taken into account in the Taylor type approach and for which central bank watchers hope to get information from wording analyses:

$$
i_{t}^{F}=\eta i_{t}^{T}+(1-\eta) i_{t}^{O} .
$$

These other aspects are, e.g., captured in the "judgement factor" as introduced by Svensson (2003). Thus, for the determination of the supplementing interest rate, $i_{t}^{O}$, communication of the central bank becomes relevant. Only in the extreme case where the Taylor type rule explains the monetary world completely, both target interest rates are identical and the target rate of the fully specified model equals the Taylor type interest rate. The supplementing interest rate can be explained by the intended change of the interest rate, $\Delta i_{t}^{O}$, based on the interest rate of the last period, $i_{t}^{O}=i_{t-1}+\Delta i_{t}^{O}$.

For the specification of the Taylor type equation, we follow GerLach (2004) and Rosa and Verga (2005) and use the inflation rate, $\pi$, the output gap, or a related measure, money growth, $\Delta m$, and the annual growth rate of the real effective exchange rate, $\Delta e$, as explanatory variables. Reflecting the availability of monthly data we generally use lagged values. Using the data published in the ECB Monthly Bulletin, we adopt the publication lag of this periodical as well and assume that this delay of data reflects the information set of the public fairly well. In addition to that we take into account that the Monthly Bulletin is published at the end of the month whereas interest rate decisions are taken at the beginning of the month as a general rule. From the view of the central bank watcher, this adds a further lag to the explanatory variables. For the inflation rate, we have a two month lag since November 2001. Before that date as well as in February 2005 and February 2006, the publication lag is three months due to the delay in the Monthly Bulletin of two months. For money growth, there is a four months lag, and for the real exchange rate measure the publication lags two months. The long lag for money growth arises because we rely on the centred three month moving average. For the measure of the output gap, the lag depends on the time series used. Because we rely on the economic sentiment indicator published by the European Commission, esi, the lag is one month. This results in the following equation:

$$
i_{t}^{T}=\alpha+\beta \pi_{t-2}+\gamma e s i_{t-1}+\delta \Delta m_{t-4}+\theta \Delta e_{t-2} .
$$


In the following, we proceed with two variants of this equation:

Backward-looking specification: Following the argumentation of CARSTENSEN (2006), we first employ an estimation function that is based on variables known at the time the central bank takes its decision. In this case, the basic variables inflation rate and output gap should be completed by estimators that help to explain the future inflation rate. We use money growth as such a variable. We label this approach as "backward-looking", because it contains only lagged variables (see also Nelson, 2003):

$$
\begin{aligned}
i_{t}^{*}-i_{t-1}= & \Delta^{*} i_{t} \\
= & -(1-\rho) \eta i_{t-1} \\
& \quad+(1-\rho)\left[\begin{array}{l}
\eta\left(\alpha+\beta \pi_{t-2}+\gamma e s i_{t-1}+\delta \Delta m_{t-4}+\theta \Delta e_{t-2}\right) \\
+(1-\eta) \Delta i_{t}^{O}
\end{array}\right]+\varepsilon_{t},
\end{aligned}
$$

where $\varepsilon$ denotes the error term.

Forward-looking specification: Going back to Clarida, Galí, and Gertler (1998) and in line with the ongoing literature on Taylor type rules (e.g. SAUER and Sturm, 2007), reaction functions of central banks are assumed to be forward-looking in the sense, that the specification of equation (4) contains the inflation forecasts, $\pi^{f}$, of the ECB. Because the staff projections of the ECB do not provide a monthly time series of forecasts, we need a proxy for these data. We use Consensus forecasts undertaken by experts as an approximation for ECB forecasts.

$$
\begin{aligned}
i_{t}^{*}-i_{t-1}= & \Delta^{*} i_{t} \\
= & -(1-\rho) \eta i_{t-1} \\
& \quad+(1-\rho)\left[\begin{array}{l}
\eta\left(\alpha+\beta \pi_{t}^{f}+\gamma \text { esi } i_{t-1}+\delta \Delta m_{t-4}+\theta \Delta e_{t-2}\right) \\
+(1-\eta) \Delta i_{t}^{O}
\end{array}\right]+\varepsilon_{t}
\end{aligned}
$$

In the estimation, we add the lagged change of the interest rate, $\Delta i$, as proposed in Judd and Rudebusch (1998) or Galí et al. (2004) in order to account for the short-run dynamics of the process. Since the ECB council decides on the target rates in a discretionary way (increase, no change, decrease), an ordered probit estimation approach is appropriate (GALí et al., 2004). Here, we work with two 
variants. In the first, the ordered dependent variable for depicting monetary policy decisions has three values, $\Delta^{3} i$, -1 (interest rate reduction), 0 (no change), 1 (interest rate increase), considering only the direction of the change. In the second variant used as a robustness check, the dependent variable has five values, $\Delta^{5} i$, and takes account of the fact that the ECB changes the interest rate either in 0.25 or (rarely) 0.5 percentage point steps resulting in the following ordering: -2 (interest rate reduction by 0.5 percentage points), -1 (reduction by 0.25 percentage points), 0 (no change), 1 (increase by 0.25 percentage points) and 2 (increase by 0.5 percentage points).

\section{Data Issues}

The following data are used: The interest rate is the interest rate of the Main Refinancing Operations. The annual inflation rate, $\pi$, is based on the harmonized index of consumer prices HICP. For money growth, we use the seasonally adjusted annual growth rate of the monetary aggregate M3 as centred moving average of three months. The annual growth rate of the exchange rate is based on the real CPI effective exchange rate index (narrow definition). Because we are interested in the reaction of the central bank, we should reproduce the knowledge that the central bank has at the time of its decision (Orphanides, 2001). To match the state of knowledge of the central bank and its watchers as close as possible, we rely on the publications in the Monthly Bulletins of the ECB for collecting real time data (for a detailed description of some special time series see appendix Table B). While revisions of the inflation rate, money growth and the annual change of the real exchange rate are moderate, the output gap is usually confronted with larger revisions. Therefore, we rely on survey data. The seasonally adjusted series of the economic sentiment indicator, published by the European Commission, is used in the form $100(e s i-\overline{e s i}) / \overline{e s i}$, where $\overline{e s i}$ denotes the mean of the series (GALí et al. 2004). For inflation forecasts the mean of the forecast published on a monthly basis by Consensus Economics (Consensus Forecasts G-7 Countries \& Western Europe) is used. Because the forecasts are given for the current and next calendar year, a conversion is needed to get forecasts with a horizon of 12 months. We do this by weighting the values for the current and next calendar year according to the publication month.

We employ the wording indicator, $W I$, lagged one month as a proxy for $\Delta i_{t}^{O}$. Thus, the explanatory value of this indicator is to reveal the extent to which rhetoric signals contain information about the monetary decision process which is not included in the standard Taylor type approach variables and in this sense offers an informative added value in the sense of hypothesis 2 . Using the wording 
indicator we face the problem that in rare cases not every month has seen an ECB press conference (8 cases) and sometimes two of these events in one month occur (3 cases). No press conferences were given in August each year until 2005 as well as in January 2001. We treat the missing value problem by interpolation using the adjacent values of the preceding and the following month. In months with two press conferences (March 2000, October 2000 and June 2001) we use the index of the second conference because the information is updated compared to the first one and, therefore, more relevant for the following interest rate decisions.

Table 3 shows descriptive statistics of the explanatory variables. The data cover the period January 1999 to December 2006 except for the interest rate change dummies starting in February 1999 and the moving average of money growth in May 1999. The maximum interest rate steps are \pm 0.5 percentage points. The real economic sentiment indicator displays the highest variance closely followed by the exchange rate variable.

Table 3: Descriptive Statistics of Used Time Series (1999:1-2006:12)

\begin{tabular}{lcccccccccc}
\hline & $i$ & $\Delta^{3} i$ & $\Delta^{5} i$ & $\pi$ & $\pi^{f}$ & $e s i$ & $\Delta m$ & $\Delta e$ & $\mathrm{WI}_{10}$ & $\mathrm{WI}_{05}$ \\
\hline $\begin{array}{l}\text { Number of } \\
\text { observations }\end{array}$ & 96 & 95 & 95 & 96 & 96 & 95 & 92 & 96 & 96 & 96 \\
Mean & 2.91 & 0.07 & 0.02 & 2.10 & 1.80 & -0.87 & 6.73 & 1.02 & -0.01 & -0.01 \\
Median & 2.75 & 0 & 0 & 2.20 & 1.80 & -2.49 & 6.85 & 1.75 & -0.13 & -0.13 \\
Maximum & 4.75 & 1.00 & 2.00 & 3.40 & 2.23 & 14.01 & 8.70 & 16.40 & 2.70 & 2.69 \\
Minimum & 2.00 & -1.00 & -2.00 & 0.80 & 1.13 & -14.53 & 4.79 & -12.80 & -2.46 & -2.06 \\
Std. Dev. & 0.89 & 0.47 & 0.67 & 0.52 & 0.25 & 7.36 & 1.15 & 7.04 & 0.88 & 0.80 \\
\hline
\end{tabular}

\section{Estimation Results}

According to our testing strategy described in section 2, we basically estimate three variants of a model explaining ECB interest rate changes. The starting point is the baseline model (Model 1) which still ignores information from the wording indicator. In order to test hypothesis 1 , we contrast this approach, first, with a "naïve" central bank watcher model where no information is used but wording and the interest rate's history (Model 2). Third, a Taylor type equation augmented by the wording indicator constitutes a test for the informative added value of wording in the sense of hypothesis 2 (Model 3). 
We apply this testing strategy to both, the full period 1999:01-2006:12 and to the sub-period 2002:01-2006:12. The sub-period testing is an "out of sample" exercise with regard to the wording indicator which has been constructed on the experience with the ECB's coding over a full interest rate cycle covering the first three years of the ECB's existence. Thus, this robustness check provides a test against the risk that the results are merely driven by a possible within-sample fallacy described in section 3. Together with the backward- and forward-looking specification and the two variants of the dependent variable (resulting from the alternative treatment of the 0.5 percentage point interest rate changes) this leaves us with 20 combinations (three models, two variants of the dependent variable, backward- and forward-looking for equations containing an inflation variable, full period and sub-period; note that for the naïve model the backward- and forward-looking distinction is irrelevant).

The estimation results show satisfactory outcomes for all models and are marked by a high joint significance of all parameters as the LR-statistics shows (see Tables 4 and 5). The estimates are quite robust regardless whether three or five categories for the interest rate changes are considered. The parameters $\mu_{1}$ to $\mu_{4}$ denote the estimated thresholds distinguishing between categories of the interest rate changes - with four (two) thresholds for the dependent variable $\Delta^{5} i\left(\Delta^{3} i\right)$. For the sub-period, there is no interest rate raise of 0.5 percentage points. This leads to one threshold less in case of then four categories of interest rate changes. As the $\chi^{2}$ statistics of a Wald test for the equality of adjacent thresholds shows, the thresholds are statistically different from each other for the full period estimations. For the sub-period, the model fails to distinguish between large and small interest rate cuts.

The estimation for the baseline model reproduces frequent findings of Taylor type regressions: The probability of interest rate increases is affected positively by the economic sentiment (as our output gap measure) and money growth. In contrast, a positive growth rate of the real exchange rate results in a higher probability of an interest rate cut. The lagged change of the interest rate is to reveal smoothing behaviour so that the negative sign is in line with theoretical expectations. However, the inflation rate does not seem to influence interest rate decisions, regardless whether a forward- or a backward-looking specification is employed. The reason could be that the inflation rate is fairly stable around two percent displaying to little variation for a significant influence. For the shorter estimation period, only the lagged change of the policy rate, the economic sentiment and the exchange rate variable are still significant and show the expected sign.

The main results for the comparative performance of the three model variants are robust, independent from the backward- and forward-specification and 
Table 4: Coefficients of the Ordered Probit Estimation, Full Period (z-statistic in Brackets, Significance at the $1\left({ }^{* *}\right), 5\left({ }^{* *}\right), 10\left(^{*}\right)$ Percent Level)

\begin{tabular}{|c|c|c|c|c|c|c|c|c|c|c|}
\hline \multirow{4}{*}{ Adj. sample } & \multicolumn{6}{|c|}{ Backward-looking } & \multicolumn{4}{|c|}{ Forward-looking } \\
\hline & \multirow{2}{*}{\multicolumn{2}{|c|}{$\begin{array}{c}\text { Base line } \\
\text { 1999:6-2006:12 }\end{array}$}} & \multirow{2}{*}{\multicolumn{2}{|c|}{$\begin{array}{l}\text { Naïve model } \\
\text { 1999:2-2006:12 }\end{array}$}} & \multirow{2}{*}{\multicolumn{2}{|c|}{$\begin{array}{l}\text { Augmented model } \\
\text { 1999:5-2006:12 }\end{array}$}} & \multicolumn{2}{|c|}{ Base line } & \multicolumn{2}{|c|}{ Augmented model } \\
\hline & & & & & & & & 1999:5- & 2006:12 & \\
\hline & (1) & (1a) & (2) & (2a) & (3) & (3a) & (1b) & (1c) & (3b) & (3c) \\
\hline$i_{t-1}$ & $\begin{array}{l}-0.82^{* *} \\
(-2.07)\end{array}$ & $\begin{array}{l}-0.94^{* *} \\
(-2.18)\end{array}$ & $\begin{array}{l}-0.50^{* * *} \\
(-2.61)\end{array}$ & $\begin{array}{l}-0.50^{* * *} \\
(-2.65)\end{array}$ & $\begin{array}{l}-0.92^{* *} \\
(-2.02)\end{array}$ & $\begin{array}{l}-1.09^{* *} \\
(-2.21)\end{array}$ & $\begin{array}{l}-0.88^{* *} \\
(-2.26)\end{array}$ & $\begin{array}{l}-0.99^{* *} \\
(-2.33)\end{array}$ & $\begin{array}{l}-1.03^{* *} \\
(-2.23)\end{array}$ & $\begin{array}{l}-1.14^{* *} \\
(-2.36)\end{array}$ \\
\hline$\Delta i_{t-1}$ & $\begin{array}{l}-4.38^{* * *} \\
(-2.88)\end{array}$ & $\begin{array}{l}-4.22^{* * *} \\
(-2.93)\end{array}$ & & & $\begin{array}{l}-6.40^{* * *} \\
(-3.35)\end{array}$ & $\begin{array}{l}-6.22^{* * *} \\
(-3.50)\end{array}$ & $\begin{array}{l}-4.39^{* * *} \\
(-2.83)\end{array}$ & $\begin{array}{c}-4.28^{* * *} \\
(-2.91)\end{array}$ & $\begin{array}{c}-6.21^{* * *} \\
(-3.33)\end{array}$ & $\begin{array}{c}-6.22^{* * *} \\
(-3.49)\end{array}$ \\
\hline$\pi_{t-2}$ or $\pi_{t}^{f}$ & $\begin{array}{l}-0.56 \\
(-1.11)\end{array}$ & $\begin{array}{l}-0.50 \\
(-1.09)\end{array}$ & & & $\begin{array}{l}-0.58 \\
(-1.00)\end{array}$ & $\begin{array}{l}-0.48 \\
(-0.97)\end{array}$ & $\begin{array}{l}-1.06 \\
(-0.93)\end{array}$ & $\begin{array}{l}-1.15 \\
(-1.07)\end{array}$ & $\begin{array}{l}-0.67 \\
(-0.57)\end{array}$ & $\begin{array}{l}-0.96 \\
(-0.88)\end{array}$ \\
\hline$e s i_{t-1}$ & $\begin{array}{l}0.25^{* * *} \\
(3.92)\end{array}$ & $\begin{array}{l}0.25^{* * *} \\
(3.95)\end{array}$ & & & $\begin{array}{l}0.20^{* * *} \\
(2.84)\end{array}$ & $\begin{array}{l}0.20^{* *} \\
(2.86)\end{array}$ & $\begin{array}{l}0.27^{* * *} \\
(4.00)\end{array}$ & $\begin{array}{c}0.28^{* * *} \\
(4.17)\end{array}$ & $\begin{array}{c}0.22^{* * *} \\
(2.97)\end{array}$ & $\begin{array}{c}0.22^{* * *} \\
(3.09)\end{array}$ \\
\hline$\Delta m_{t-4}$ & $\begin{array}{l}1.07^{* * *} \\
(3.23)\end{array}$ & $\begin{array}{l}0.89^{* * *} \\
(2.95)\end{array}$ & & & $\begin{array}{l}1.19^{* * *} \\
(3.17)\end{array}$ & $\begin{array}{l}0.96^{* * *} \\
(3.00)\end{array}$ & $\begin{array}{l}1.14^{* * *} \\
(3.04)\end{array}$ & $\begin{array}{l}0.98^{* * *} \\
(2.87)\end{array}$ & $\begin{array}{l}1.21^{* * *} \\
(2.98)\end{array}$ & $\begin{array}{l}1.02^{* * *} \\
(2.91)\end{array}$ \\
\hline$\Delta e_{t-2}$ & $\begin{array}{l}-0.12^{*} \\
(-1.89)\end{array}$ & $\begin{array}{l}-0.12^{* *} \\
(-2.01)\end{array}$ & & & $\begin{array}{l}-0.12^{*} \\
(-1.83)\end{array}$ & $\begin{array}{l}-0.13^{* *} \\
(-2.06)\end{array}$ & $\begin{array}{l}-0.12^{*} \\
(-1.87)\end{array}$ & $\begin{array}{l}-0.12^{*} \\
(-1.95)\end{array}$ & $\begin{array}{l}-0.12^{*} \\
(-1.80)\end{array}$ & $\begin{array}{c}-0.13^{* *} \\
(1.99)\end{array}$ \\
\hline$W I_{t-1}$ & & & $\begin{array}{l}1.13^{* * *} \\
(5.00)\end{array}$ & $\begin{array}{l}1.16^{* * *} \\
(5.24)\end{array}$ & $\begin{array}{l}1.10^{* * *} \\
(2.47)\end{array}$ & $\begin{array}{l}1.07^{* * *} \\
(2.68)\end{array}$ & & & $\begin{array}{l}1.07^{* *} \\
(2.43)\end{array}$ & $\begin{array}{l}1.06^{* * *} \\
(2.67)\end{array}$ \\
\hline
\end{tabular}




\begin{tabular}{|c|c|c|c|c|c|c|c|c|c|c|}
\hline \multirow{4}{*}{ Adj. sample } & \multicolumn{6}{|c|}{ Backward-looking } & \multicolumn{4}{|c|}{ Forward-looking } \\
\hline & \multirow{2}{*}{\multicolumn{2}{|c|}{$\begin{array}{c}\text { Base line } \\
\text { 1999:6-2006:12 }\end{array}$}} & \multirow{2}{*}{\multicolumn{2}{|c|}{$\begin{array}{c}\text { Naïve model } \\
\text { 1999:2-2006:12 }\end{array}$}} & \multirow{2}{*}{\multicolumn{2}{|c|}{$\begin{array}{l}\text { Augmented model } \\
\text { 1999:5-2006:12 }\end{array}$}} & \multicolumn{2}{|c|}{ Base line } & \multicolumn{2}{|c|}{ Augmented model } \\
\hline & & & & & & & & 1999:5 & $006: 12$ & \\
\hline & (1) & (1a) & $(2)$ & (2a) & (3) & $(3 a)$ & (1b) & (1c) & (3b) & (3c) \\
\hline$\mu_{1}$ & -0.03 & -2.02 & -3.31 & -3.65 & 0.35 & -2.06 & -0.58 & -2.68 & 0.15 & -2.62 \\
\hline$\mu_{2}$ & 5.76 & -1.50 & -0.03 & -3.30 & 6.45 & -1.51 & 5.30 & -2.18 & 6.28 & -2.06 \\
\hline$\mu_{3}$ & & 4.30 & & -0.01 & & 4.63 & & 3.72 & & 4.13 \\
\hline$\mu_{4}$ & & 6.08 & & 1.18 & & 6.61 & & 5.52 & & 6.12 \\
\hline$\chi^{2}$ statistics & $25.78^{* * *}$ & $\begin{array}{c}3.54^{*} \\
26.47^{* * *} \\
14.12^{* * *}\end{array}$ & $76.68^{* * *}$ & $\begin{array}{c}3.31^{*} \\
77.81^{* * *} \\
12.25^{* * *}\end{array}$ & $25.23^{* * *}$ & $\begin{array}{c}3.59^{*} \\
25.34^{* * *} \\
14.42^{* * *}\end{array}$ & $25.61^{* * *}$ & $\begin{array}{c}3.54^{*} \\
27.12^{* * *} \\
13.99^{* * *}\end{array}$ & $24.44^{* * *}$ & $\begin{array}{c}3.59^{*} \\
25.67^{* * *} \\
14.39^{* * *}\end{array}$ \\
\hline Log likelihood & -28.11 & -37.88 & -48.33 & -58.01 & -24.59 & -33.90 & -28.31 & -37.89 & -24.94 & -33.97 \\
\hline Pseudo $\mathrm{R}^{2}$ & 0.54 & 0.47 & 0.25 & 0.23 & 0.60 & 0.52 & 0.54 & 0.47 & 0.59 & 0.52 \\
\hline LR stat. (const.) & $65.52^{* * *}$ & $66.71^{* * *}$ & $31.61^{* * *}$ & $34.00^{* * *}$ & $72.56^{* * *}$ & $74.68^{* * *}$ & $65.13^{* * *}$ & $66.68^{* * *}$ & $71.87^{* * *}$ & $74.52^{* * *}$ \\
\hline Q-stat. (lag 1) & $4.21^{* *}$ & $3.67^{*}$ & $3.00^{*}$ & $6.35^{* *}$ & $5.74^{* *}$ & $8.07^{* * *}$ & $4.76^{* *}$ & $4.08^{* *}$ & $5.25^{* *}$ & $8.12^{* * *}$ \\
\hline Q-stat. (lag 12) & 16.36 & 13.25 & 16.02 & $18.62^{*}$ & 17.27 & $19.10^{*}$ & 16.56 & 13.22 & 16.25 & $18.86^{*}$ \\
\hline
\end{tabular}


Table 5: Coefficients of the Ordered Probit Estimation, Sub-period

(z-Statistic in Brackets, Significance at the $1\left(^{(* *}\right), 5(* *), 10\left(^{*}\right)$ Percent Level)

\begin{tabular}{|c|c|c|c|c|c|c|c|c|c|c|}
\hline \multirow{4}{*}{ Adj. sample } & \multicolumn{6}{|c|}{ Backward-looking } & \multicolumn{4}{|c|}{ Forward-looking } \\
\hline & \multicolumn{2}{|c|}{ Base line } & \multirow{2}{*}{\multicolumn{2}{|c|}{$\begin{array}{c}\text { Naïve model } \\
\text { 2002:1 - 2006:12 }\end{array}$}} & \multicolumn{2}{|c|}{ Augmented model } & \multicolumn{2}{|c|}{ Base line } & \multicolumn{2}{|c|}{ Augmented model } \\
\hline & & & & & & & & 2002:1 & 2006:12 & \\
\hline & (4) & $(4 a)$ & (5) & (5a) & (6) & (6a) & (4b) & $(4 c)$ & (6b) & (6c) \\
\hline$i_{t-1}$ & $\begin{array}{l}-0.75 \\
(-0.85)\end{array}$ & $\begin{array}{l}-0.83 \\
(-0.88)\end{array}$ & $\begin{array}{l}-0.22 \\
(-0.54)\end{array}$ & $\begin{array}{l}-0.24 \\
(-0.59)\end{array}$ & $\begin{array}{l}-0.91 \\
(-0.91)\end{array}$ & $\begin{array}{l}-1.06 \\
(-0.98)\end{array}$ & $\begin{array}{l}-0.86 \\
(-1.05)\end{array}$ & $\begin{array}{l}-0.92 \\
(-1.07)\end{array}$ & $\begin{array}{l}-0.74 \\
(-0.63)\end{array}$ & $\begin{array}{l}-0.88 \\
(-0.72)\end{array}$ \\
\hline$\Delta i_{t-1}$ & $\begin{array}{l}-11.52^{* *} \\
(-2.37)\end{array}$ & $\begin{array}{l}-10.59^{* *} \\
(-2.40)\end{array}$ & & & $\begin{array}{l}-11.08^{* *} \\
(-1.98)\end{array}$ & $\begin{array}{c}-10.97^{*} \\
(-1.90)\end{array}$ & $\begin{array}{l}-11.06^{* *} \\
(-2.47)\end{array}$ & $\begin{array}{l}-10.33^{* *} \\
(-2.46)\end{array}$ & $\begin{array}{l}-12.25^{*} \\
(-1.89)\end{array}$ & $\begin{array}{c}-12.33^{*} \\
(-1.78)\end{array}$ \\
\hline$\pi_{t-2}$ or $\pi_{t}^{f}$ & $\begin{array}{c}0.49 \\
(0.29)\end{array}$ & $\begin{array}{c}0.35 \\
(0.22)\end{array}$ & & & $\begin{array}{l}-0.42 \\
(-0.18)\end{array}$ & $\begin{array}{l}-0.83 \\
(-0.34)\end{array}$ & $\begin{array}{c}1.23 \\
(0.27)\end{array}$ & $\begin{array}{c}1.77 \\
(0.39)\end{array}$ & $\begin{array}{l}-4.16 \\
(-0.62)\end{array}$ & $\begin{array}{l}-4.26 \\
(-0.63)\end{array}$ \\
\hline$e s i_{t-1}$ & $\begin{array}{l}0.35^{* * *} \\
(2.71)\end{array}$ & $\begin{array}{l}0.35^{* *} \\
(2.47)\end{array}$ & & & $\begin{array}{c}0.24 \\
(1.49)\end{array}$ & $\begin{array}{c}0.24 \\
(1.38)\end{array}$ & $\begin{array}{c}0.31^{*} \\
(1.94)\end{array}$ & $\begin{array}{c}0.30^{*} \\
(1.84)\end{array}$ & $\begin{array}{c}0.36 \\
(1.33)\end{array}$ & $\begin{array}{c}0.37 \\
(1.30)\end{array}$ \\
\hline$\Delta m_{t-4}$ & $\begin{array}{l}1.47 \\
(1.47)\end{array}$ & $\begin{array}{c}1.12 \\
(1.11)\end{array}$ & & & $\begin{array}{c}1.23 \\
(1.38)\end{array}$ & $\begin{array}{l}1.09 \\
(1.47)\end{array}$ & $\begin{array}{c}1.38 \\
(1.40)\end{array}$ & $\begin{array}{c}1.06 \\
(1.10)\end{array}$ & $\begin{array}{c}1.35 \\
(1.38)\end{array}$ & $\begin{array}{c}1.19 \\
(1.53)\end{array}$ \\
\hline$\Delta e_{t-2}$ & $\begin{array}{l}-0.19^{*} \\
(-1.74)\end{array}$ & $\begin{array}{l}-0.16^{* *} \\
(-1.59)\end{array}$ & & & $\begin{array}{l}-0.21^{*} \\
(-1.73)\end{array}$ & $\begin{array}{l}-0.20^{*} \\
(-1.72)\end{array}$ & $\begin{array}{l}-0.18^{*} \\
(-1.66)\end{array}$ & $\begin{array}{l}-0.15 \\
(-1.51)\end{array}$ & $\begin{array}{l}-0.24^{*} \\
(-1.76)\end{array}$ & $\begin{array}{l}-0.23^{*} \\
(-1.70)\end{array}$ \\
\hline$W I_{t-1}$ & & & $\begin{array}{l}1.71^{* * *} \\
(3.47)\end{array}$ & $\begin{array}{l}1.77^{* * *} \\
(3.54)\end{array}$ & $\begin{array}{l}1.63^{*} \\
(1.79)\end{array}$ & $\begin{array}{l}1.85^{* *} \\
(1.98)\end{array}$ & & & $\begin{array}{c}1.91^{*} \\
(1.81)\end{array}$ & $\begin{array}{l}2.08^{* *} \\
(1.99)\end{array}$ \\
\hline
\end{tabular}




\begin{tabular}{|c|c|c|c|c|c|c|c|c|c|c|}
\hline \multirow{4}{*}{ Adj. sample } & \multicolumn{6}{|c|}{ Backward-looking } & \multicolumn{4}{|c|}{ Forward-looking } \\
\hline & \multicolumn{2}{|c|}{ Base line } & \multirow{2}{*}{\multicolumn{2}{|c|}{$\begin{array}{c}\text { Naïve model } \\
\text { 2002:1 - 2006:12 }\end{array}$}} & \multicolumn{2}{|c|}{ Augmented model } & \multicolumn{2}{|c|}{ Base line } & \multicolumn{2}{|c|}{ Augmented model } \\
\hline & & & & & & & & 2002:1 - & $006: 12$ & \\
\hline & (4) & $(4 a)$ & (5) & $(5 a)$ & (6) & (6a) & (4b) & $(4 c)$ & $(6 \mathrm{~b})$ & (6c) \\
\hline$\mu_{1}$ & 3.53 & 0.47 & -3.03 & -3.37 & -0.59 & -3.39 & 4.30 & 2.69 & -7.27 & -9.62 \\
\hline$\mu_{2}$ & 11.69 & 0.78 & 0.82 & -3.10 & 7.28 & -2.97 & 12.23 & 3.00 & 1.30 & -9.19 \\
\hline$\mu_{3}$ & & 8.42 & & 0.79 & & 4.89 & & 10.46 & & -0.52 \\
\hline$\chi^{2}$ statistics & $9.17^{* * *}$ & $\begin{array}{c}1.12 \\
10.46^{* * *}\end{array}$ & $43.95^{* * *}$ & $\begin{array}{c}1.07 \\
43.59^{* * *}\end{array}$ & $9.38^{* * *}$ & $\begin{array}{l}1.50 \\
8.68^{* * *}\end{array}$ & $10.40^{* * *}$ & $\begin{array}{c}1.12 \\
10.99^{* * *}\end{array}$ & $6.73^{* * *}$ & $\begin{array}{l}1.16 \\
6.04^{* *}\end{array}$ \\
\hline Log likelihood & -11.25 & -13.63 & -22.95 & -24.48 & -9.31 & -11.071 & -11.26 & -13.57 & -9.10 & -10.90 \\
\hline Pseudo $\mathrm{R}^{2}$ & 0.64 & 0.59 & 0.26 & 0.26 & 0.70 & 0.66 & 0.64 & 0.59 & 0.71 & 0.67 \\
\hline LR stat. (const.) & $39.68^{* * *}$ & $37.75^{* * *}$ & $16.29^{* * *}$ & $17.03^{* * *}$ & $43.56^{* * *}$ & $43.86^{* * *}$ & $39.67^{* * *}$ & $38.85^{* * *}$ & $43.98^{* * *}$ & $44.21^{* * *}$ \\
\hline Q-stat. (lag 1) & $2.64^{*}$ & 1.91 & 0.35 & 0.39 & $5.15^{* *}$ & $5.16^{* *}$ & $2.66^{*}$ & 1.73 & $7.00^{* * *}$ & $6.60^{* *}$ \\
\hline Q-stat. (lag 12) & $25.08^{* *}$ & $19.70^{*}$ & $24.40^{* *}$ & $24.58^{* *}$ & $28.17^{* *}$ & $25.72^{* *}$ & $25.73^{* *}$ & $19.71^{*}$ & $30.82^{* * *}$ & $25.60^{* *}$ \\
\hline
\end{tabular}


independent from the covered estimation period. With regard to our key interest variable, the wording indicator, the results are as follows: The augmentation of the baseline by the wording indicator hints to an informative added value of wording. The indicator turns out to be significant in the full period regression as well as in sub-period regression at least at the 10 percent level. The positive sign is as expected since a higher indicator value signals a larger extent of "hawkishness" and the probability of an interest rate raise increases. In addition to that, the regressions' fit increase with the inclusion of the wording indicators. A more formal testing of this point indicates that the reaction function improves significantly with the inclusion of the wording indicator, at least at the 5 percent level (see Table 6).

Table 6: LR Test Statistics for the Inclusion of the Wording Indicator

\begin{tabular}{|c|c|c|c|c|c|c|c|c|}
\hline & \multicolumn{4}{|c|}{ Full period (1999:6-2006:12) } & \multicolumn{4}{|c|}{ Sub-period (2002:1-2006:12) } \\
\hline & \multicolumn{2}{|c|}{ Backward-looking } & \multicolumn{2}{|c|}{ Forward-looking } & \multicolumn{2}{|c|}{ Backward-looking } & \multicolumn{2}{|c|}{ Forward-looking } \\
\hline & 3 categ. & 5 categ. & 3 categ. & 5 categ. & 3 categ. & 5 categ. & 3 categ. & 5 categ. \\
\hline LR statistic $(1 \mathrm{df})$ & $7.04^{* * *}$ & $7.96^{* * *}$ & $6.74^{* * *}$ & $7.84^{* * *}$ & $3.88^{* *}$ & $5.12^{* *}$ & $4.32^{* *}$ & $5.34^{* *}$ \\
\hline
\end{tabular}

Critical $\chi^{2}$-values: 2.71 (10\%), 3.84 (5\%), 6.63 (1\%)

The naïve model based solely on the wording indicator and past values of the interest rate clearly shows a poorer fit compared to the baseline model and the extended model. Even though the wording indicator is significant, it cannot replace other macroeconomic variables that help to explain the interest rate decisions of the ECB. The drop of explanatory power is considerable compared to the more elaborate models. However, the increasing size of the coefficient relative to that of the lagged interest rate shows that the variable tries to capture the influence of the other macroeconomic variables.

To evaluate whether the indicator is not only statistically significant but also helps to improve the prediction of interest rate changes, we display the classification of policy rate changes for the different models with backward-looking specification (see Table 7a and 7b). By including the wording indicator into the Taylor type equation, the error in classifying interest changes decreases. This result applies not only for the analysis of the whole period but also for the subperiod which has not taken account of in the wording indicator construction algorithm. 
Table 7a: Classifications of Interest Rate Changes, Three Categories

\begin{tabular}{|c|c|c|c|c|c|c|}
\hline & \multicolumn{6}{|c|}{$\begin{array}{l}\text { Correct classifications of interest rate changes } \\
\text { (observations with maximum probability) }\end{array}$} \\
\hline & $\begin{array}{l}\text { 1999:5- } \\
2006: 12\end{array}$ & $\begin{array}{l}\text { 1999:2- } \\
2006: 12\end{array}$ & $\begin{array}{l}\text { 1999:5- } \\
\text { 2006:12 }\end{array}$ & & $\begin{array}{l}2002: 1- \\
2006: 12\end{array}$ & \\
\hline & $\begin{array}{c}(1) \\
\text { Basic } \\
\text { model }\end{array}$ & $\begin{array}{l}(2) \\
\text { Naive } \\
\text { model }\end{array}$ & $\begin{array}{c}(3) \\
\text { Augmented } \\
\text { model }\end{array}$ & $\begin{array}{c}(4) \\
\text { Basic } \\
\text { model }\end{array}$ & $\begin{array}{c}(5) \\
\text { Naive } \\
\text { model }\end{array}$ & $\begin{array}{c}(6) \\
\text { Augmented } \\
\text { model }\end{array}$ \\
\hline$\Delta i<0$ & 3 of 7 & 0 of 7 & 3 of 7 & 1 of 3 & 0 of 3 & 1 of 3 \\
\hline$\Delta i=0$ & 65 of 71 & 67 of 71 & 66 of 71 & 48 of 51 & 50 of 51 & 49 of 51 \\
\hline$\Delta i>0$ & 9 of 13 & 3 of 13 & 10 of 13 & 4 of 6 & 2 of 6 & 5 of 6 \\
\hline
\end{tabular}

Table 7b: Classifications of Interest Rate Changes, Five Categories

\begin{tabular}{|c|c|c|c|c|c|c|}
\hline & \multicolumn{6}{|c|}{$\begin{array}{l}\text { Correct classifications of interest rate changes } \\
\text { (observations with maximum probability) }\end{array}$} \\
\hline & $\begin{array}{l}\text { 1999:5- } \\
2006: 12\end{array}$ & $\begin{array}{l}1999: 2- \\
2006: 12\end{array}$ & $\begin{array}{l}\text { 1999:5- } \\
\text { 2006:12 }\end{array}$ & & $\begin{array}{l}2002: 1- \\
2006: 12\end{array}$ & \\
\hline & $\begin{array}{c}(1 \mathrm{a}) \\
\text { Basic } \\
\text { model }\end{array}$ & $\begin{array}{l}(2 a) \\
\text { Naive } \\
\text { model }\end{array}$ & $\begin{array}{c}(3 \mathrm{a}) \\
\text { Augmented } \\
\text { model }\end{array}$ & $\begin{array}{c}(4 a) \\
\text { Basic } \\
\text { model }\end{array}$ & $\begin{array}{c}(5 a) \\
\text { Naive } \\
\text { model }\end{array}$ & $\begin{array}{c}(6 a) \\
\text { Augmented } \\
\text { model }\end{array}$ \\
\hline$\Delta i=-0.5$ & 1 of 4 & 0 of 4 & 1 of 4 & 0 of 2 & 0 of 2 & 1 of 2 \\
\hline$\Delta i=-0.25$ & 0 of 3 & 0 of 3 & 0 of 3 & 0 of 1 & 0 of 1 & 0 of 1 \\
\hline$\Delta i=0$ & 67 of 71 & 68 of 71 & 67 of 71 & 48 of 51 & 50 of 51 & 49 of 51 \\
\hline$\Delta i=0.25$ & 7 of 11 & 1 of 11 & 8 of 11 & 4 of 6 & 2 of 6 & 5 of 6 \\
\hline$\Delta i=0.5$ & 0 of 2 & 0 of 2 & 1 of 2 & - & - & - \\
\hline
\end{tabular}

Two interest rate changes more are correctly classified for the three and five category version for the complete as well as the shorter time period. For the detailed interest rate changes of the sub-period, an improvement of even three classifications is achieved. Again the poor performance of the naïve approach (2), (2a) and (5), (5a) becomes apparent. Especially changing interest rates are not clas- 
sified correctly whereas unchanged interest rates are more likely classified with this model than with the other two setups.

The results are basically unchanged if we replace the wording indicator calculated on the basis of a 5 percent significance level in the algorithm's ANOVA by a variant based on a 10 percent significance level (results not reported, available on request from the authors). However, the wording indicator based on the 5 percent significance level is more selective and gives somewhat better results.

Summing up, the findings lead to the rejections of hypothesis 1: Central bank watching and de-coding of wording cannot be a substitute for thorough model analyses. However, hypothesis 2 is not rejected: ECB Wording indeed includes information helpful to improve the explanation of interest rate decisions based on standard explanatory models.

\section{Conclusions}

In this paper's title we pose the question „Does it pay to watch central bankers' lips"? Judging on the experience with the ECB we answer this question in the affirmative. Compared to technical approaches based on standard Taylor type equations and solely hard economic data the exploitation of rhetoric signals can be helpful to better explain what the central bank is doing. This result is confirmed on the basis of an out of sample analysis where the period on which the wording indicator's choice of weights is based is not included in testing this indicator's significance. Thus, we tend to accept the hypothesis that wording includes information helpful to improve the explanation of interest rate decisions based on standard explanatory models. This also indicates that Taylor type regressions are not able to capture the realities of monetary policy completely - a fact which seems sometimes to be ignored in the literature.

It should be stressed that our wording indicator based on statistical reasoning is nevertheless rather mechanical and only an approximation for the information content of wording. It cannot capture the art of reading between the lines of central bankers' statements. In this sense our results for the informative contents of wording must be regarded to be of a conservative nature. Furthermore, the algorithm does not yet allow for a constant learning and updating that would incorporate new nuances in ECB wording. The modelling of permanent learning processes on the side of ECB observers is left to future research.

Although our analysis hints to the usefulness of rhetoric signals it also indicates its limitation. Market participants benefiting from a correct prediction of monetary decisions are well advised to employ also more rigorous models for their 
forecasts in addition to listening to ECB press conferences. Our findings largely indicate that judgements based solely on analysing central bankers' speeches are inferior to more refined approaches based on models and economic data.

\section{Appendix}

Table A: Potential Code Words with Examples of Use

\begin{tabular}{ll}
\hline Code word & Examples \\
\hline appropriate & The Governing Council concluded that the information which had \\
become available in recent weeks confirmed that the current level of \\
key ECB interest rates remains appropriate for the maintenance of price \\
stability over the medium term (7 March 2002). \\
Overall, the current monetary policy stance remains appropriate to \\
preserve a favourable outlook for price stability in the medium term \\
(6 February 2003). \\
We judge the current monetary policy stance appropriate to maintain \\
a favourable outlook for price stability in the medium term. Hence, we \\
have decided to keep our key rates unchanged (9 January 2003). \\
On the basis of our regular economic and monetary analysis, we have \\
not changed our assessment that the current stance of monetary policy \\
remains in line with the maintenance of price stability over the medium \\
term (1 April 2004). \\
In summary, the economic analysis indicates that the main scenario for \\
price developments in the medium term continues to be in line with our \\
definition of price stability (4 December 2003). \\
To sum up, the economic analysis continues to indicate that the main \\
scenario for price developments in the coming years is in line with price \\
stability. Cross-checking with the monetary analysis does not alter this \\
picture for the time being (4 March 2004). \\
For the time being, we thus see a confirmation of our earlier assessment, \\
which led us to reduce the key ECB interest rates by 50 basis points \\
on 17 September. In fact, the recent events strengthened tendencies \\
towards lower rates of inflation that were already prevailing before (11 \\
October 2001). \\
Over the coming months, volatility in annual inflation rates is likely \\
to be observed, mainly due to further base effects from energy prices as \\
well as to increases in indirect taxes (4 March 2004). \\
As I have already noted on previous occasions, the rise in the Harmo- \\
nised Index of Consumer Prices (HICP) which we have observed over \\
recent months stems, to a large extent, from the combined effects of \\
both oil price and exchange rate developments (13 April 2000). \\
observe
\end{tabular}




\begin{tabular}{ll}
\hline Code word & Examples \\
\hline monitor & The Governing Council will carefully monitor future developments \\
and assess whether conditions for price stability continue to develop \\
favourably (8 May 2003). \\
In view of the high uncertainty on future growth, and its implication for \\
medium-term inflationary developments, the Governing Council has \\
discussed extensively the arguments for and against a cut in the key ECB \\
interest rates. The view has prevailed to keep interest rates unchanged. \\
However, the Governing Council will monitor closely the downside risks \\
to economic growth in the euro area (7 November 2002). \\
As always, we will continue to monitor carefully all developments that \\
could affect our assessment of risks to price stability over the medium \\
term (6 May 2004). \\
The Eurosystem will remain vigilant in assessing upside risks to price \\
stability and will take appropriate action if and when required (13 April \\
2000). \\
The Governing Council will remain vigilant with regard to all develop- \\
ments which could affect the risks to price stability over the medium
\end{tabular}
term (1 July 2004).

risks to price stability We will remain vigilant with regard to all developments which could affect the risks to price stability over the medium term (4 June 2004).

As always, we will continue to monitor carefully all developments that could affect our assessment of risks to price stability over the medium term (6 May 2004).

upsidelupward risks to To sum up, annual inflation rates should fall below $2 \%$ in 2005 , but a price stability number of medium-term upside risks to price stability need to be carefully monitored (7 October 2004).

upsidelupward Over the short term, oil prices continue to exert upward pressure on the pressure on inflation general price level (1 July 2004).

Due to the increase in oil prices, some renewed upward pressure on consumer prices is likely to have emerged around the turn of the year (9 January 2003).

I noted earlier that, from a monetary policy point of view, these developments are a cause for concern as they add to the upward pressure on consumer prices in the euro area (14 September 2000).

downsideldownward Overall, with regard to the cyclical situation, recent data confirm our risks to growth/ economic activity earlier expectations that there are still downside risks for output growth (4 March 1999).

Sources of downside risks - including oil prices, imbalances in the global economy, financial market uncertainties and their impact on consumption, investment, and thus on employment - will be monitored closely (10 October 2002). 


\begin{tabular}{|c|c|}
\hline Code word & Examples \\
\hline \multirow[t]{2}{*}{ second round effects } & $\begin{array}{l}\text { These risks relate mainly to oil price developments and their potential } \\
\text { to lead to second-round effects stemming from wage and price-setting } \\
\text { behaviour ( } 7 \text { July 2005). }\end{array}$ \\
\hline & $\begin{array}{l}\text { Inflation rates are now approaching higher levels than expected earlier, } \\
\text { and larger and more protracted commodity and producer price increases } \\
\text { are heightening the risk of second round effects ( } 3 \text { February 2000). }\end{array}$ \\
\hline
\end{tabular}

The Eurosystem will remain vigilant in assessing upside risks to price stability and will take appropriate action if and when required (13 April 2000).

alert The Governing Council will continue to remain alert to emerging risks to price stability (14 September 2000).

mixed signals Recent data and survey indicators on economic activity have been mixed. In general they point to ongoing economic growth at a moderate pace over the short term, with no clear signs as yet of a strengthening in underlying dynamics (7 April 2005).

Our conclusion was that while risks to price stability over the medium term remain tilted to the upside, recent evidence sends mixed signals (4 July 2002).

favourable outlook for Reflecting favourable domestic and external conditions for growth, the growth outlook for euro area growth continues to be positive (6 July 2000).

The more favourable expectations for economic development in the euro area are partly connected with a further improved outlook for the world economy (7 October 1999).

favourable outlook for Overall, the Governing Council confirmed its previous assessment of price stability a favourable outlook for price stability in the euro area over the medium term (4 March 2004).

We judge the current monetary policy stance appropriate to maintain a favourable outlook for price stability in the medium term (9 January 2003).

compatible/consistent with price stability

Overall, as several indicators are pointing to an abatement of inflationary pressures, the new level of interest rates is compatible with the maintenance of price stability over the medium term (30 August 2001).

Markets still expect an evolution of consumer prices, which will remain compatible with price stability (9 September 1999).

balanced
Our conclusion is that risks to price stability are at present balanced (10 October 2002)

The decision to keep interest rates unchanged reflects the Governing Council's assessment that the risks to price stability in the medium term now appear more balanced than at the end of last year (1 February 2001). 


\begin{tabular}{|c|c|}
\hline Code word & Examples \\
\hline \multirow[t]{2}{*}{ economic slowdown } & $\begin{array}{l}\text { First, when looking back, we recognise that inflation has been rather } \\
\text { persistent despite the economic slowdown ( } 5 \text { December 2002). }\end{array}$ \\
\hline & $\begin{array}{l}\text { First, the slowdown in economic activity which I just mentioned may con- } \\
\text { tribute to containing inflationary pressure stemming from the labour } \\
\text { market ( } 30 \text { August 2001). }\end{array}$ \\
\hline
\end{tabular}

Table B: Data Sources

\begin{tabular}{|c|c|}
\hline $\begin{array}{l}\text { Money growth M3, } \\
\text { centred moving } \\
\text { average, seasonally } \\
\text { adjusted }\end{array}$ & $\begin{array}{l}\text { - first published in August } 2001 \text { (Mai } 2001 \text { value) } \\
\text { - January } 1999 \text { - April 2001: calculated from the seasonally adjusted } \\
\text { index of M3 } \\
\text { - August 1999: first publication of seasonally adjusted index (May } \\
\text { 1999 value) } \\
\text { - January } 1999 \text { - April 1999: Index values taken from the August } 1999 \\
\text { Monthly Bulletin }\end{array}$ \\
\hline $\begin{array}{l}\text { Annual real } \\
\text { effective exchange } \\
\text { rate change }\end{array}$ & $\begin{array}{l}\text { - January 1999: calculated from the indices published in the Febru- } \\
\text { ary } 1999 \text { Monthly Bulletin } \\
\text { - Before April 2000: effective exchange rate change for the countries, } \\
\text { displayed in the Monthly Bulletin } \\
\text { - Since April 2000: narrow group of trading partners } \\
\text { - January } 2001 \text { - December 2001: growth rates are calculated using } \\
\text { the Table "Past data for selected economic indicators for the euro } \\
\text { area plus Greece" }\end{array}$ \\
\hline
\end{tabular}

\section{References}

Andersson, Malin, Hans Dillén and Peter Sellin (2001), "Monetary Policy Signaling and Movements in the Swedish Term Structure of Interest Rates", Sveriges Riksbank Working Paper No. 132.

Beine Michel and Christelle Lecourt (2004), "Reported and Secret Interventions in the Foreign Exchange Markets", Finance Research Letters, 1, pp. 215-225.

Berger, Helge, Michael Ehrmann and Marcel Fratzscher (2006a), "Monetary Policy in the Media", ECB Working Paper No. 679.

Berger, Helge, Jakob de Haan and Jan-Egbert Sturm (2006b), "Does Money Matter in the ECB Strategy? New Evidence Based on ECB Communication", CESifo Working Paper No. 1652. 
Bernoth, Kerstin und Jürgen von Hagen (2004), "The Euribor Futures Market: Efficiency and the Impact of ECB Policy Announcements", International Finance, 7, pp. 1-24.

Carstensen, Kai (2006), "Estimating the ECB Policy Reaction Function", German Economic Review, 7, pp. 1-34.

Clarida, Richard, Jordi Galí and Mark Gertler (1998), "Monetary Policy Rules in Practice: Some International Evidence", European Economic Review, 42, pp. 1033-1067.

Conley, Timothy, Bill Dupor and Tokhir Mirzoev (2004), "Does the Federal Reserve Do What It Says It Expects to Do?”, Working Paper, mimeo.

Ehrmann, Michael and Marcel Fratzscher (2005), "Communication and Decision-making by Central Bank Committees. Different Strategies, Same Effectiveness?", ECB Working Paper No. 488.

Faust, Jon, Eric T. Swanson and Jonathan H. Wright (2004), "Do Federal Reserve Policy Surprises Reveal Superior Information about the Economy?", Contributions to Macroeconomics, 4, pp. 1-29.

Fratzscher, Marcel (2004), "Communication and Exchange Rate Policy", ECB Working Paper No. 363.

Galí, Jordi, Stefan Gerlach, Julio Rotemberg, Harald Uhlig and Michael Woodford (2004), "The Monetary Policy Strategy of the ECB Reconsidered." Monitoring the European Central Bank 5, CEPR, London.

Gaspar, Vítor, Gabriel Pérez Quiros and Jorge Sicilia (2001), "The ECB Monetary Policy Strategy and the Money Market", ECB Working Paper No. 69.

Gerlach, Stefan (2004), "Interest Rate Setting by the ECB: Words and Deeds", CEPR Discussion Paper No. 4775.

Guthrie, Graeme and Julian Wright (2000), "Open Mouth Operations, Journal of Monetary Economics”, 46, pp. 489-516.

Heinemann, Friedrich and Felix Hüfner (2004), "Is the View from the Eurotower Purely European? National Divergence and ECB Interest Rate Policy", Scottish Journal of Political Economy, 51, pp. 544-557.

Jansen, David-Jan and Jakob de HaAn (2004a), "Look Who's Talking: ECB Communications During the First Years of EMU”, CESifo Working Paper No. 1263.

Jansen, David-Jan and Jakob de HaAn (2004b), "Statements of ECB Officials and their Effect on the Level and Volatility of the Euro-Dollar Exchange Rate", CESifo Working Paper No. 927. 
Jansen, David-Jan and Jakob de HaAn (2005), "Is a Word to the Wise Indeed Enough? ECB Statements and the Predictability of Interest Rate Decisions", DNB Working Paper No. 75.

Judd, John P. and Glenn D. Rudebusch (1998), “Taylor's Rule and the Fed: 1970-1997”, FRBSF Economic Review, 3, pp.3-16.

Kohn, Donald L. and Brian P. SaCk (2003), "Central Bank Talk: Does It Matter and Why", Federal Reserve Board Finance and Economics Discussion Series No. 55.

Lamla, Michael J. and Sarah M. Rupprecht (2006), “The Impact of ECB Communication on Financial Market Expectations", Swiss Institute for Business Cycle Research (KOF), Swiss Federal Institute of Technology Zurich (ETH), Working Paper No. 06-135,

Mayer, Thomas (2004), “The Risks to Price Stability", Deutsche Bank, Global Markets Research, Focus Europe, 19 July 2004, pp.7-9.

Orphanides, Athanasios (2001), "Monetary Policy Rules on Real-time Data", American Economic Review, 91, pp. 964-985.

Nelson, Edward (2003), "UK Monetary Policy 1972-97: A Guide Using Taylor Rules", in Mizen, P. (ed.), Central Banking, Monetary Theory and Practice: Essays in Honour of Charles Goodhart. Edward Elgar, Cheltenham, pp. 195-216.

Reeves, Rachel and Michael Sawicki (2005), "Do Financial Markets React to Bank of England Communication?", Bank of England Quarterly Bulletin, Winter 2005, pp.431-439.

Rosa, Carlo and Giovanni Verga (2005), "The Importance of Wording of the ECB”, Centre for Economic Performance Discussion Paper No. 694.

Ross, Kevin (2002), "Market Predictability of ECB Monetary Policy Decisions: A Comparative Examination", IMF Working Paper No. 233.

Sauer, Stephan and Jan-Egbert Sturm (2007), "Using Taylor Rules to Understand ECB Monetary Policy", German Economic Review, forthcoming.

Svensson, Lars E.O. (2003), "What Is Wrong with Taylor Rules? Using Judgment in Monetary Policy through Targeting Rules", Journal of Economic Literature, 41 (2), pp. 426-477.

Taylor, John B. (1993), "Discretion versus Policy Rules in Practice", CarnegieRochester Conference Series on Public Policy, 39, pp. 195-214.

Wilhelmsen, Bjørn-Roger and Andrea Zaghini (2005), "The Importance of the Wording of the ECB", ECB Discussion Paper No. 504.

Without Author (2003), „Glossar der geldpolitischen Signalsprache der EZB“, Börsenzeitung, Nr. 152, 9. August 2003: 7. 


\section{SUMMARY}

In this analysis, the informational content of central bank rhetoric is assessed based on the experience with the ECB since 1999. Among the ECB's communication channels we focus on the monthly press conferences. Based on a counting of certain signal words we construct a wording indicator reflecting the "hawkishness" of monetary rhetorics. For the construction, we develop an objective algorithm. We then integrate this indicator into a standard Taylor type ordered probit model for the explanation of the interest rate. We show that the wording indicator can improve the model's fit when added to the standard explanatory variables. However, a model based solely on this indicator performs worse than the baseline. The results are confirmed by an out of sample analysis where the determination of the wording indicators' weights is based on the early ECB period which, subsequently, is excluded from the tests. Our conclusion is that linguistic analysis can improve but not substitute more rigorous forecasting techniques based on hard economic data. 